\title{
Marine nematode taxonomy in the age of DNA: the present and future of molecular tools to assess their biodiversity
}

\author{
Neyvan Renato Rodrigues DA Silva ${ }^{1,2,3,4, *}$, Maria CRISTINA DA Silva ${ }^{1}$, \\ Verônica Fonseca Genevois ${ }^{1}$, André Morgado Esteves ${ }^{1}$, Paul De LeY ${ }^{5}$, \\ Wilfrida DECRAEMER ${ }^{6,7}$, Tania Tassinari RIEGER ${ }^{2}$ \\ and Maria Tereza DOS SANTOS CORREIA ${ }^{4}$ \\ ${ }^{1}$ Departamento de Zoologia, Universidade Federal de Pernambuco, Av. Prof. Professor Moraes Rêgo, s/n, \\ Cidade Universitária, Recife, Brazil \\ ${ }^{2}$ Departamento de Genética,Universidade Federal de Pernambuco, Av. Prof. Professor Moraes Rêgo, s/n, \\ Cidade Universitária, Recife, Brazil \\ ${ }^{3}$ Instituto Federal do Rio Grande do Norte, Campus Zona Norte, Rua Brusque 2926, Potengi, Natal, \\ Rio Grande do Norte, Brazil \\ ${ }^{4}$ Departamento de Bioquímica, Universidade Federal de Pernambuco, Av. Prof. Professor Moraes Rêgo, s/n, \\ Cidade Universitária, Recife, Brazil \\ ${ }^{5}$ Department of Nematology, University of California, Riverside, CA 92521, USA \\ ${ }^{6}$ Department of Biology, Ghent University, Ledeganckstraat 35, B 9000, Ghent, Belgium \\ ${ }^{7}$ Royal Belgian Institute of Natural Sciences, Vautierstraat 29, B 1000 Brussels, Belgium
}

Received: 12 November 2009; revised: 18 March 2010

Accepted for publication: 18 March 2010

\begin{abstract}
Summary - Molecular taxonomy is one of the most promising yet challenging fields of biology. Molecular markers such as nuclear and mitochondrial genes are being used in a variety of studies surveying marine nematode taxa. Sequences from more than 600 species have been deposited to date in online databases. These barcode sequences are assigned to 150 nominal species from 104 genera. There are 41 species assigned to Enoplea and 109 species to Chromadorea. Morphology-based surveys are greatly limited by processing speed, while barcoding approaches for nematodes are hampered by difficulties in matching sequence data with morphology-based taxonomy. DNA barcoding is a promising approach because some genes contain variable regions that are useful to discriminate species boundaries, discover cryptic species, quantify biodiversity and analyse phylogeny. We advocate a combination of several approaches in studies of molecular taxonomy, DNA barcoding and conventional taxonomy as a necessary step to enhance the knowledge of biodiversity of marine nematodes.
\end{abstract}

Keywords - barcoding, marine nematodes, molecular markers, molecular taxonomy.

The phylum Nematoda exhibits high species diversity, as well as high abundances in aquatic (marine or freshwater) and terrestrial environments (Floyd et al., 2002). Nematoda in general are one of the most diverse taxa in the animal kingdom, with estimates ranging from 0.1 to 100 million species (Lambshead, 1993; Coomans, 2002). Only a few thousand of these species have been described, although they represent the most abundant component of the meiofauna in several kinds of ecosystems (Lambshead, 2004; Bhadury et al., 2006a).
Species-level identification of most marine nematodes still relies largely on detailed morphological analysis that requires considerable taxonomic expertise, placing it outside the scope of most routine ecological surveys (De Ley et al., 2005; Bhadury et al., 2006a, b). Nematode identification using morphological characters is not only time-consuming but also problematic, mainly because of the high phenotypic plasticity among populations and the absence of clear diagnostic characters for cryptic species (Avise \& Walker, 1999; Derycke et al., 2008; Fonseca et al., 2008).

\footnotetext{
*Corresponding author, e-mail: neyvan.rodrigues@ifrn.edu.br
} 
The advent of molecular techniques has opened up new possibilities for taxonomic research and has provided an important tool, given that the vast majority of species are not well differentiated morphologically (Godfray, 2002; Seberg et al., 2003; Vogler \& Monaghan, 2007). These new techniques improve taxonomic precision and assist in critical examinations of the accuracy afforded by morphological traits that are commonly used in traditional taxonomy (Will \& Rubinoff, 2004). Indeed, several studies have already illustrated the advances afforded by the interactive process between morphology and DNA 'barcoding' for systematics ( $\alpha$-taxonomy and phylogeny) (Blaxter, 2004; Hebert et al., 2004; Lee, 2004; Hebert \& Gregory, 2005).

DNA barcoding appears to be a promising tool to inventory the biodiversity of free-living marine nematodes (Blaxter et al., 2005; Bhadury et al., 2006a; Meldal et al., 2007; Derycke et al., 2008). DNA barcode sequences have proved useful in identifying clades and evolutionary relationships (De Ley \& Blaxter, 2002, 2004; Savolainen et al., 2005).

Large-scale application of molecular data is revolutionising taxonomy, but the validity and relevance of molecular approaches and the concepts on which these techniques are based have been subject to a variety of criticisms (Lipscomb et al., 2003; Wheeler, 2004; Rubinoff et al., 2006; Kohler, 2007; Valdecasas et al., 2008).

This survey presents an overview of molecular approaches for marine nematode taxa, dealing with DNA taxonomy, barcoding, and molecular taxonomy. We also discuss the application of molecular markers that are presently used in studies in molecular taxonomy, and the present number of barcoded sequences available in public databases for marine nematodes. We discuss the prospects for future studies with barcoding of marine nematodes, using multiple approaches such as microarrays, new sequencing technology and metagenomics to elucidate relationships among new taxa.

\section{DNA taxonomy and barcoding for marine nematodes}

The history of nematode systematics has been marked by controversy, not only as a result of the development of diverse classification systems but also because relatively few nematologists produce detailed classifications (De Ley \& Blaxter, 2002). Nematode identification using morphological characters is often difficult and laborious. To make matters worse, there is no generally accepted species concept by which we can define the unit used, and, furthermore, nematode species can be variable in morphology, and differences between valid species can be obscured by the absence of clear diagnostic differences (De Ley et al., 1999; Derycke et al., 2006, 2007). Although nematodes have been studied for over 100 years, objective criteria for assessing the homology of morphological characters used in phylogenetic reconstructions within the phylum are still lacking (Chilton et al., 2003).

By contrast, the concept of DNA-based taxonomy as proposed by Tautz et al. (2003) is essentially based on the barcoding approach as its practical component. The basic procedure of this approach consists of a tissue sample, taken from an individual, from which DNA is extracted. This DNA serves as the reference sample from which one or several gene regions are amplified by PCR and sequenced. The resulting sequence will be an identification tag for the species from which the respective individual was derived (Lipscomb et al., 2003; Mallet \& Willmott, 2003; Marshall, 2005). The advocates of taxonomy based mainly on DNA sequences claim that the current practice in morphological taxonomy is not adequate to achieve the aim of a reasonably complete inventory of animal life in a reasonable period of time (Stoeckle, 2003).

Proponents of DNA barcoding have argued that we could use DNA sequences of one or more particular genes to identify nematode species, based on the idea that every species has its own 'diagnostic' sequences, i.e., unique sets of base-pair mutations (Hollingsworth, 1998; Kohler, 2007). The three main aims of DNA barcoding are to: $i$ ) assign unknown specimens to species; $i i$ ) enhance the discovery of new species and facilitate identification, particularly in cryptic microscopic and other organisms with complex or inaccessible morphology; and iii) increase massively the speed of processing larger data sets (Hebert \& Gregory, 2005; Frézal \& Leblois, 2008).

DNA barcoding promises rapid, accurate identification of species or molecular operational units by focusing on a short standardised segment of the genome (Hajibabaei et al., 2007). At the gene level it provides, in many animal groups, strong species-level resolution, for example, for birds (Hebert et al., 2004), spiders (Barret \& Hebert, 2005), fishes (Ward et al., 2005), and lepidopterans (Janzen et al., 2005). Building upon the idea of the Universal Product Code, found in commercial products as 'barcodes' (Brown, 1997), a few nucleotides may well provide an immediate diagnosis for species (Hebert et al., 2003a; DeSalle et al., 2005; Savolainen et al., 2005). 
One of the main disadvantages occurs in sampling shortfalls across taxa that lead to 'barcoding gaps' (Moritz $\&$ Cicero, 2004). Many taxa are under-represented, and conclusions based on a restricted data set may be biased (Rubinoff, 2006; Rach et al., 2008).

Recently, several authors have discussed the nature of the taxonomic problems, and potential strategies that could be used to accelerate the pace of the discovery and classification of biodiversity, with a balanced response that would maintain the role of morphology in taxonomy (Mallet \& Willmott, 2003; Sites \& Marshall, 2003). In fact, barcoding seems prone to failure, except in cases with extremely well developed background knowledge of the taxa sampled and barcoded with an a priori understanding of sequence variation among populations and individuals (Wilson, 2004).

\section{Molecular markers for taxonomy of marine nematodes}

In an effort to standardise the approach to species identification using molecular techniques, it has been proposed that as many species as possible should be characterised for some genetic markers (Sunnucks, 2000; Blaxter, 2004). However, the main difficulty in molecular taxonomy is to find the ideal gene that discriminates a given species in the animal kingdom.

Several molecular markers have been proposed. The nuclear subunit ribosomal RNA gene is a promising candidate because of its great abundance in the genome and its relatively conserved flanking regions that can provide classifications into molecular taxonomic units (MOTU), as has been shown in meiofauna specimens, including nematodes (Floyd et al., 2002; Blaxter et al., 2005).

There is intense selection in the ribosomal DNA genes because of their vital role in the assembly of proteins in the ribosome. As a consequence, these genes - or at least parts of them - are strongly conserved. Among the ribosomal RNA encoding genes, the small subunit (SSU) rDNA is the most conserved (Holterman et al., 2006).

\section{NUCLEAR GENES}

The SSU rDNA gene has proved to be very useful for exploring the phylogenetic relationships within, as well as between, many (though not all) groups of nematodes. The semi-conserved areas in the gene allow the unravelling of the deep phylogenetic relationships within the phylum yet, at the same time, the more variable regions in the gene have enabled investigators to distinguish between families or genera, and, in quite a few cases, even between species (Aleshin et al., 1998; Holterman et al., 2008).

Especially among invertebrates, the SSU rDNA is usually present in several copies that code for SSU rRNA. SSU rDNA sequences are known for a broad range of terrestrial nematode fauna, and are sufficiently variable to permit the differentiation of closely related nematode species (Gasser \& Newton, 2000; Fontanilla \& Wade, 2008). Consequently, SSU rDNA has received the most attention as a barcoding locus in recent literature (Cook et al., 2005; Bhadury et al., 2006a). The locus has higher phylogenetic information content, with small amounts of polymorphism, and often works well for resolving relationships at different levels of classification (e.g., Félix et al., 2000; Rusin et al., 2003; Foucher et al., 2004).

The LSU rDNA gene has been used for almost 10 years as a source of diagnostic sequences in nematodes, particularly the region that spans the D2 and D3 expansion segments (Thomas et al., 1997; Zheng et al., 2003; Tenente et al., 2004; Subbotin et al., 2007; Fonseca et al., 2008; Kumari et al., 2009). In nematodes, this region covers about $600-1000 \mathrm{bp}$, fairly close to the $5^{\prime}$ end of the gene. In contrast, the conserved regions alternating with D2 and D3 are highly constant, even across phyla, and provide very robust primer sites. According to De Ley et al. (2005), the D2/D3 primer pair has the highest success rate when applying PCR amplification to a phylum-wide selection of nematodes, and, based on our limited testing, it also works well in other phyla of microscopic metazoans. The locus is not known to be subject to significant levels of intraspecific polymorphism, and provides very good separation of cryptic species in some groups (De Ley et al., 1999). Previous studies have included phylogenetic applications of D2 or D3 alone (Litvaitis et al., 2000).

The Internal Transcribed Spacer (ITS) region is another versatile genetic marker located in the repeating array of nuclear $18 \mathrm{~S}$ and $28 \mathrm{~S}$ ribosomal DNA genes. The ITS has been used in constructing phylogenetic trees, estimating genetic population structures, evaluating populationlevel evolutionary processes and determining taxonomic identity (Powers et al., 1997). In marine nematodes, ITS showed highly divergent phylogenetic lineages caused by a common evolutionary process in the Pellioditis marina species-complex and the genetic structure of Halomonhystera disjuncta. This marker has not been considered a good universal identification tool in marine nematodes for two reasons: $i$ ) intra-individual variation is fre- 
quently observed, which reduces the sequencing signal; and $i$ ) a large number of indel events are present within closely related cryptic taxa, rendering alignment between divergent taxa problematic (Derycke et al., 2007, 2008) (Table A1; Fig. 1).

\section{MitOCHONDRIAL GENES}

The mitochondrial gene, cytochrome c oxidase subunit 1 (COI), has been proposed as a candidate locus for a 'universal' diagnostic barcode (Lorenz et al., 2005). COI is widely used for barcoding animals. Current barcoding studies have primarily focused on a single mitochondrial marker as a source of identifying diagnostic bar- codes (Rach et al., 2008). Mitochondrial genes such as COI could also provide further information on gene-flow patterns and cryptic-level diversity within marine nematodes. However, amplification of this gene in marine nematodes is extremely difficult and unreliable (Bhadury et al., 2006b).

To date, there are no phylum-wide universal primers for the mitochondrial cytochrome oxidase I gene that work across the Nematoda, and PCR success rates are well below $50 \%$ for various taxa within the phylum (De Ley et al., 2005). The reasons for these problems may relate to the emerging evidence that nematode mitochondrial genomes are highly diverse, displaying unusual proper-

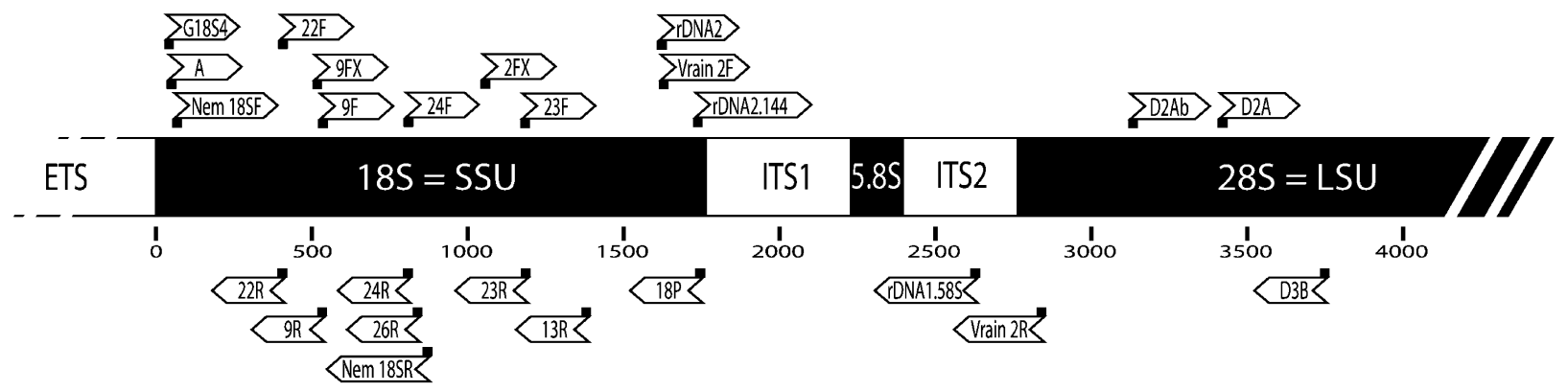

Fig. 1. Combinations of nuclear primers used in studies of rDNA genes for molecular taxonomy of nematodes.

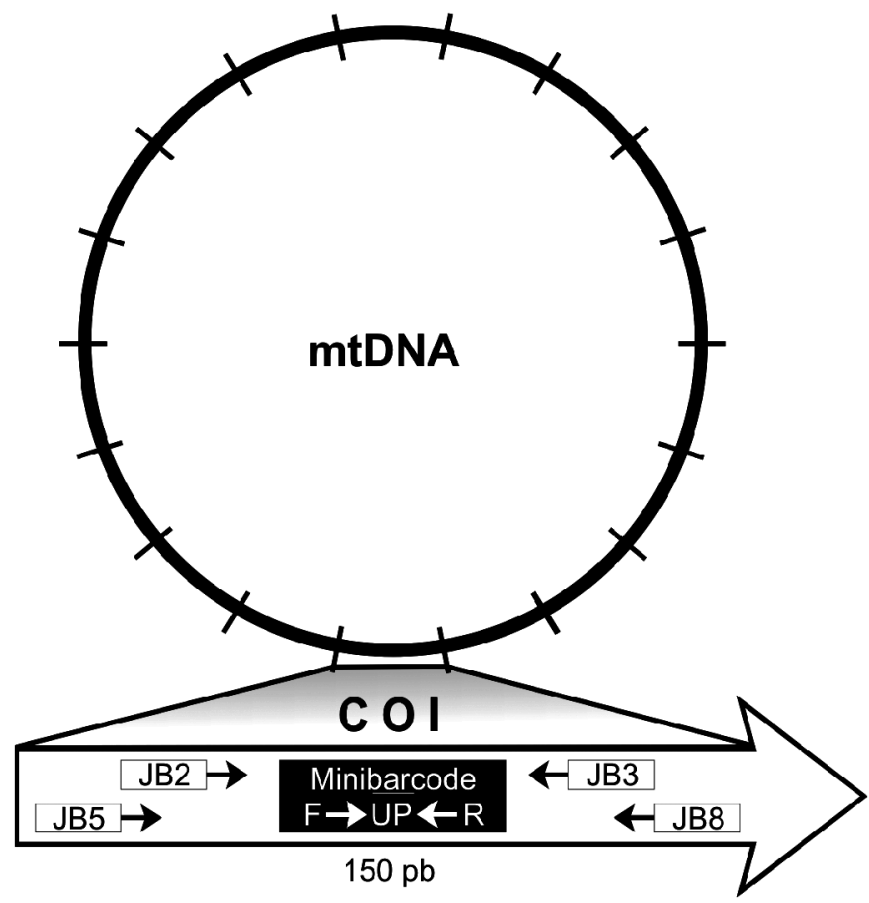

Fig. 2. Combinations of mitochondrial primers used in studies of molecular taxonomy of nematodes. 
ties such as recombination (Lunt \& Hyman, 1997), insertion editing (Vanfleteren \& Vierstraete, 1999) and multipartitioning (Armstrong et al., 2000). In addition, mitochondrial genes have higher mutation rates and a fourfold smaller effective size and, consequently, evolve more rapidly than the nuclear genes (Avise, 2000).

Mitochondrial primers are generally used for barcoding studies (Hebert et al., 2003a, b). Derycke et al. (2005, 2006, 2007, 2008), using a combination of primers, succeeded in amplifying the COI gene from two nematode species, P. marina and Geomonhystera disjuncta, and showed cryptic diversity within both taxa (Fig. 2; Table A1). Fonseca et al. (2008) also used COI in a survey of integrative taxonomy in two free-living-nematode species complexes. However, it is clear that current primers are not adequate if COI-based DNA barcoding is to work. There is another combination of COI called a minibarcode (short primer for COI segment with $150 \mathrm{bp}$ ) that was used to identify the minimum amount of sequence information required for accurate species identification
(Meusnier et al., 2008). This primer set was tested in marine nematodes and showed high PCR success rates, but the sequences produced showed a lack of phylogenetic signal for discriminating relationships among nematode species (Silva et al., unpubl. data) (Fig. 2; Table A1). Thereafter, with the sequencing of new mitochondrial genes, new insights on how to apply other mtDNA can become helpful in studies of molecular taxonomy of marine nematodes.

\section{AVAILABLE SEQUENCED DATA OF MARINE NEMATODES}

A total of 600 barcode sequences of marine nematodes have been deposited in the NCBI to date. These barcode sequences were assigned to 150 nominal species from 104 genera. In total, barcoded sequences of 41 species were assigned to Enoplea (Fig. 3) and 109 species to Chromadorea (Fig. 4). Within the latter class, the most sequenced family is Chromadoridae (with 18 species),

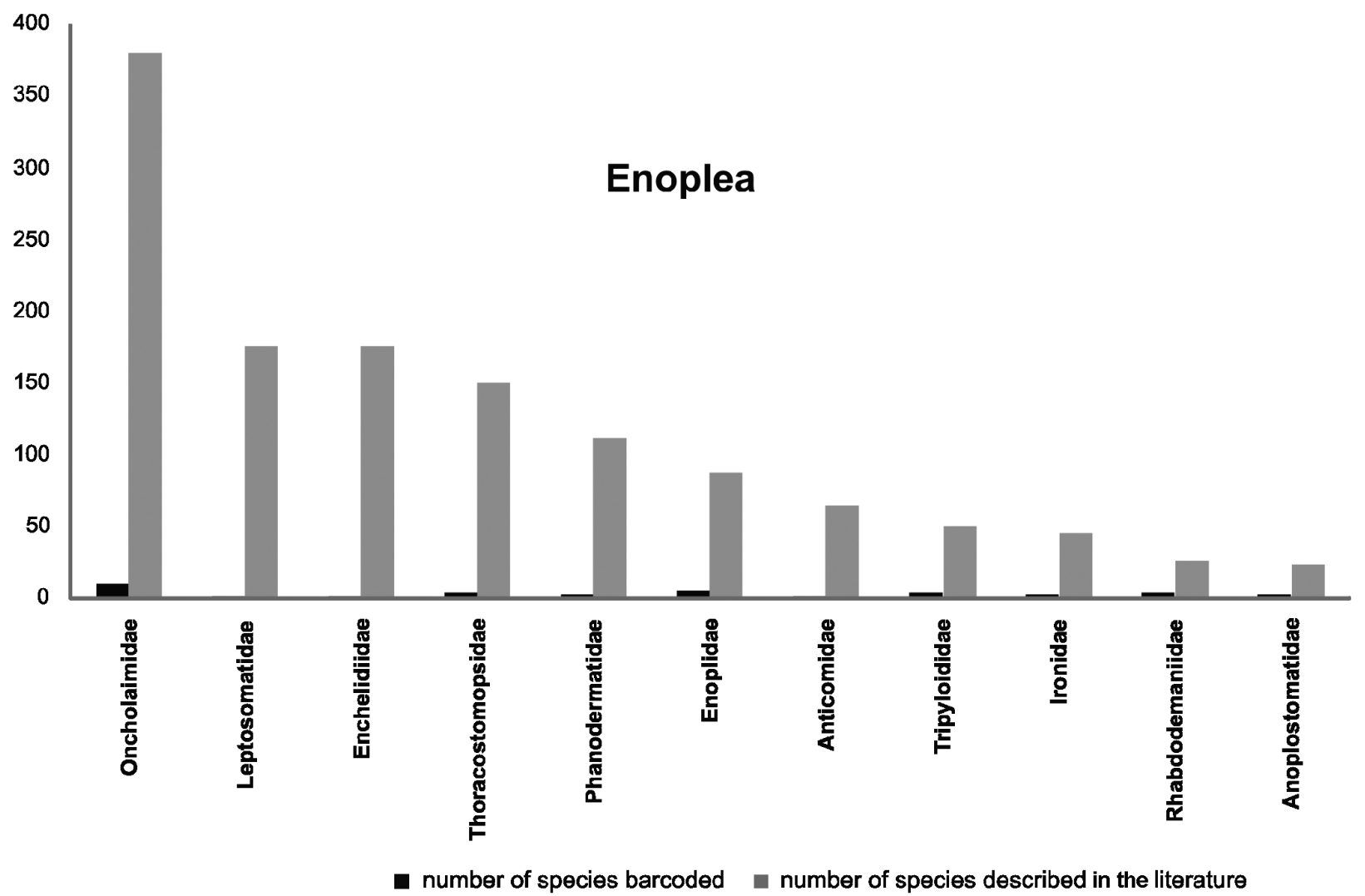

Fig. 3. Estimated number of nematode species barcoded for SSU/LSU/COI markers in class Enoplea, compared to the number of described nematode species. Source: http://www.nemys.com 


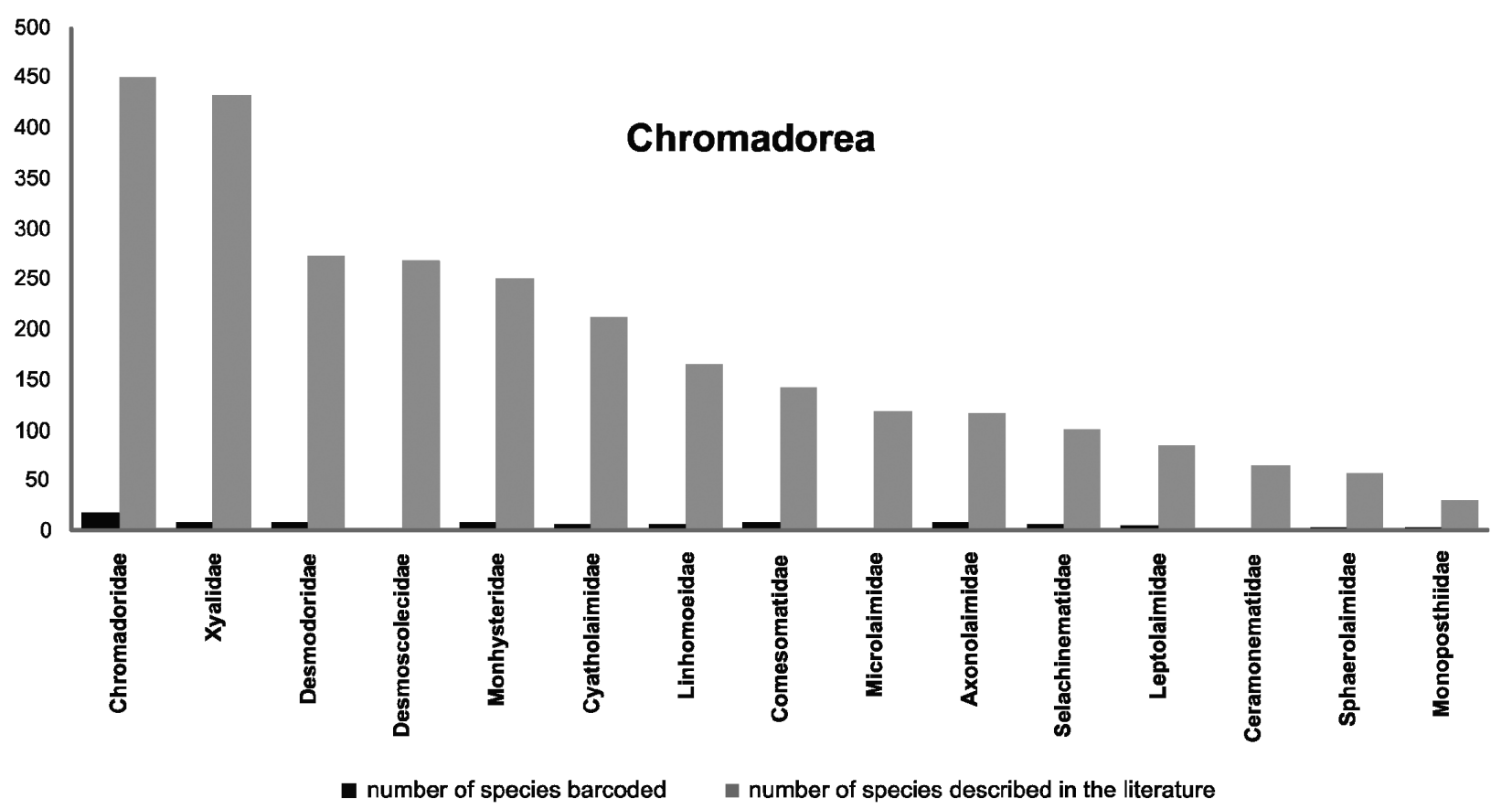

Fig. 4. Estimated number of nematode species barcoded for SSU/LSU/COI markers in class Chromadorea, compared to the number of described nematode species. Source: http://www.nemys.com

followed by Desmodoridae, Ethmolaimidae and Xyalidae with nine species each.

According to our analysis, genera of the families Chromadoridae and Oncholaimidae have the largest number of species sequences deposited in GenBank. However, fewer than 20 species are represented, whereas the genus $\mathrm{On}$ cholaimus alone has more than 30 valid species described. The number of marine nematode species with barcode sequences in databases is very low compared with the diversity of the phylum. Other nematode groups such as plant parasites are better represented in genetic databases. More sequences are needed in order to increase the number of molecular tags in nematodes. This reinforces the necessity to produce more sequences in studies dealing with free-living taxa in order to increase the number of molecular tags in nematodes. Additional 18S rRNA, COI and $28 \mathrm{~S}$ sequences from different marine nematode taxa are required in order for the barcoding approach to be more accurate and useful.

\section{FUTURE STUDIES WITH DNA BARCODING IN MARINE NEMATODES}

Two principal elements are proposed in DNA barcoding: $i$ ) the ability to assign an unknown sample to a known species; and ii) the ability to detect previously collected species as distinct. The prospect of assigning an unknown sample to a known one is promising, especially for well known, comprehensively sampled, groups that have been extensively studied by genetic and morphological taxonomy (Meyer \& Paulay, 2005).

Nevertheless, it is clear that a comprehensive comparative molecular database is needed against which unknown samples can be compared (Ekrem et al., 2007). The study of marine nematodes has recently focused on molecular tools to describe diversity in ecosystems, and methods of integration of morphological approaches with molecular analyses must be developed in order to cover the diversity of the group.

Several steps must be followed in order to create a DNA-based species identification system. First, we must define a comprehensive barcode sequence library of marine nematodes. Second, we must develop an effective approach for comparing and matching sequences from new specimens to the barcode library (Frézal \& Leblois, 2008). Finally, barcoding must be combined with traditional taxonomy in an attempt to integrate several aspects of the biological species concept.

Molecular analysis is making an obvious contribution to taxonomy in helping to discover cryptic species (Lee, 
2004). However, it is necessary to know the complete range of diversity of Nematoda in nature in order to understand the possible biological differences between cryptic nematode species, before applying molecular techniques to attempt to solve ecological questions.

Other technologies are available including metagenomics, a method of sequencing DNA from natural samples which thus provides access to a much wider range of genomes to capture the genomic diversity within a natural population (Tringe \& Rubin, 2005). The microarray method has been applied in some parasitic nematodes, and is a promising alternative for high-throughput genotypebased diagnostics combining powerful DNA amplification strategies with subsequent hybridisation to develop oligonucleotide probes specific for multiple target sequences, allowing parallel study of the expression of thousands of genes (Schulze \& Downward, 2001; Butte, 2002). This technology has been used to generate wholegenome characterisations of aging, wild-type and longlived individuals of the model organism Caenorhabditis elegans (Golden \& Melov, 2004).

\section{Conclusions}

Marine environments present challenges in assessing the biodiversity of nematodes, challenges that impose limitations using morphology-based species identification and which result in a gross underestimate of the number of species in these habitats; moreover, free-living marine species are poorly represented in public sequence databases. Molecular analyses of a much greater diversity of nematode species are urgently needed to improve the representation of molecular and phylogenetic diversity within this wide-ranging group of organisms.

Further evaluation is needed to select different markers for molecular studies, since a highly conserved gene such as the 18S rRNA may also vary somewhat within some marine nematode populations (Floyd et al., 2005; Bhadury et al., 2008). Hyperdiverse samples of marine nematodes are especially difficult because they may contain very few individuals of each of the many species in the samples, leaving little or no room for assessing whether slightly divergent sequences from similar individuals might represent cryptic species $v s$ being attributable to intraspecific sequence variation. Nowadays, the analysis of specimens using the combination of molecular techniques and morphological approach is helping to solve some of these problems or to support existing species complex already described (Fonseca et al., 2008).
Methods for rapid sequence acquisition are already in use at genome sequencing centres and are easily adapted for taxonomic sampling (Blaxter, 2004; Bhadury et al., 2006a, b, 2008). At the same time, morphology-based taxonomic methods should continue to be used in order to develop identification keys for new species of marine nematodes. De Ley and Bert (2002) developed a technique based on video capture editing (VCE), which produces a number of multifocal vouchers of barcoded nematode species. Voucher specimens can be deposited in an open access website database supporting the nematode branch of the tree of life (see: http://nematol.unh.edu). Hence, it is important that studies with model organisms on integrative taxonomy carefully examine the limitations of each strategy in order to choose the best one for future identifications.

Traditional marine nematode taxonomy, based on the analysis of observable morphological characters, may be insufficient if we are to understand fully the species-level biodiversity of this meiobenthic group (Bhadury et al., 2008). An expanding nuclear and mitochondrial sequence database for nematode species will need to be developed to facilitate routine identification of nematodes. The development of high-throughput systems may prove to be more time efficient than traditional microscopy for faunal samples. However, considering a combination of those procedures, it seems that molecular data - based on two or more markers - as used to code the morphological dataset for multivariate analysis, and, ultimately, for pinpointing morphological diagnostic characters, may prove to be very effective (Fonseca et al., 2008), although success in some specific cases is very different from applicability on the scale of ecological surveys. Various novel sequencing technologies are being developed, each aspiring to reduce costs with the aim of producing more sequences of nematode species to be deposited in public databases.

Although integrative taxonomy requires substantial expertise and time, the method is, at present, one of the best ways accurately to delimit species in taxa with unknown biodiversity (Will et al., 2005). Hence, taxonomic revisions are urgently required in the phylum Nematoda in order to understand the group's diversity and to make a compilation of taxonomic descriptions of nematode species.

\section{Acknowledgements}

The authors are indebted to Luciana Tosta for composing the diagrams that illustrate this paper. We acknowledge anonymous reviewers for their constructive criti- 
cism and valuable comments, which improved the quality of this manuscript. N.R. was sponsored by a Ph.D. fellowship from Petrobras and supported by the Institute of Technology of Rio Grande do Norte - North Zone.

\section{References}

Aleshin, V.V., Kedrova, O.S., Milyutina, I.A., VladyChENSKayA, N.S. \& Petrov, N.B. (1998). Relationships among nematodes based on the analysis of 18S rRNA gene sequences: molecular evidence for monophyly of chromadorian and secernentian nematodes. Russian Journal of Nematology 6, 175-184.

Armstrong, M.R., BloK, V.C. \& Phillips, M.S. (2000). A multipartite mitochondrial genome in the potato cyst nematode Globodera pallida. Genetics 154, 181-192.

AVISE, J.C. (2000). Phylogeography: the history and formation of species. Cambridge, MA, USA, Harvard University Press, $447 \mathrm{pp}$.

Avise, J.C. \& WALKeR, D. (1999). Species realities and number in sexual vertebrates: perspectives from an asexually transmitted genome. Proceedings of the National Academy of Sciences of the United States of America 96, 992-995.

BARRETT, R.D.H. \& HEBERT, P.D.N. (2005). Identifying spiders through DNA barcodes. Canadian Journal of Zoology 83, 481-491.

Bert, W., Leliaert, F., Vierstraete, A.R., VanFleteren, J.R. \& Borgonie, G. (2008). Molecular phylogeny of the Tylenchina and evolution of the female gonoduct (Nematoda: Rhabditida). Molecular Phylogenetics and Evolution 48, 728-744.

Bhadury, P., Austen, M.C., Bilton, D.T., Lambshead, P.J.D., Rogers, A.D. \& SMERdon, G.R. (2006a). Molecular detection of marine nematodes from environmental samples: overcoming eukaryotic interference. Aquatic Microbial Ecology 44, 97-103.

Bhadury, P., Austen, M.C., Bilton, D.T., Lambshead, P.J.D., Rogers, A.D. \& SMERdon, G.R. (2006b). Development and evaluation of a DNA-barcoding approach for the rapid identification of nematodes. Marine Ecology Progress Series 320, 1-9.

Bhadury, P., Austen, M.C., Bilton, D.T., Lambshead, P.J.D., Rogers, A.D. \& Smerdon, G.R. (2007). Exploitation of archived marine nematodes - a hot lysis DNA extraction protocol for molecular studies. Zoologica Scripta 36, 93-98.

Bhadury, P., Austen, M.C., Bilton, D.T., LAmbshead, P.J.D., Rogers, A.D. \& SMERDon, G.R. (2008). Evaluation of combined morphological and molecular techniques for marine nematode (Terschellingia spp.) identification. Marine Biology 154, 509-518.
BlaXter, M.L. (2004). The promise of DNA taxonomy. Philosophical Transactions of the Royal Society, London B 359, 669-679.

BlaXter, M.L., De Ley, P., Garey, J.R., LiU, L.X., Scheldemann, P., Vierstraete, A., Vanfleteren, J.R., Mackey, L.Y., Dorris, M., Frisse, L.M. ET AL. (1998). A molecular evolutionary framework for the phylum Nematoda. Nature 392, 71-75.

Blaxter, M.L., Mann, J., Chapman, T., Thomas, F., Whitton, C., Floyd, R. \& Abebe, E. (2005). Defining operational taxonomic units using DNA barcode data. Philosophical Transactions of the Royal Society, London B 360, 1935-1943.

BROWN, S.A. (1997). Revolution at the checkout counter. Cambridge, MA, USA, Harvard University Press, 38 pp.

Butte, A. (2002). The use and analysis of microarray data. Nature Reviews 1, 951-959.

Chilton, N.B., Huby-Chilton, F. \& Gasser, R.B. (2003). First complete large subunit ribosomal RNA sequence and secondary structure for a parasitic nematode: phylogenetic and diagnostic implications. Molecular and Cellular Probes 17, 33-39.

Cook, A.A., Bhadury, P., Debenham, N.J., Meldal, B.H.M., Blaxter, M.L., Smerdon, G.R., Austen, M.C., LAmbshead, P.J.D. \& Rogers, A.D. (2005). Denaturing gradient gel electrophoresis (DGGE) as a tool for identification of marine nematodes. Marine Ecology Progress Series 291, 103-113.

CoOMAns, A. (2002). Present status and future of nematode systematics. Nematology 4, 573-582.

DE LEY, P. \& BERT, W. (2002). Video capture and editing as a tool for the storage, distribution and illustration of morphological characters of nematodes. Journal of Nematology 34, 296-302.

DE LEY, P. \& BlaXter, M. (2002). Systematic position and phylogeny. In: Lee, D. (Ed.). The biology of nematodes. London, UK, Taylor \& Francis, pp. 1-30.

De Ley, P. \& BlaXter, M. (2004). A new system for Nematoda: combining morphological characters with molecular trees, and translating clades into ranks and taxa. In: Cook, R. \& Hunt, D.J. (Eds). Nematology Monographs and Perspectives, volume 2. Leiden, The Netherlands, E.J. Brill, pp. 633653.

De Ley P., Félix, M.A., Frisse, L.M., NAdler, S.A., Sternber, P.W. \& Thomas, W.K. (1999). Molecular and morphological characterization of two reproductively isolated species with mirror-image anatomy (Nematoda: Cephalobidae). Nematology 1, 591-612.

De Ley, P., De Ley, I.M., MorRis, K., Abebe, E., Mundo Ocampo, M., Yoder, M., Heras, J., Waumann, D., Rocha-Olivares, A., Burr, A.H.J. ET AL. (2005). An integrated approach to fast and informative morphological vouchering of nematodes for applications in molecular bar- 
coding. Philosophical Transactions of the Royal Society, London B 360, 1945-1958.

Derycke, S., Remerie, T., Vierstraete, A., Backeljau, T., Vanfleteren, J., VincX, M. \& Moens, T. (2005). Mitochondrial DNA variation and cryptic speciation within the free-living marine nematode Pellioditis marina. Marine Ecology Progress Series 300, 91-103.

DeRYCKe, S., BaCKelJau, T., Vlaeminck, C., VierStraete, A., Vanfleteren, J., VincX, M. \& Moens, T. (2006). Seasonal dynamics of population genetic structure in cryptic taxa of the Pellioditis marina complex (Nematoda: Rhabditida). Genetica 128, 307-321.

Derycke, S., Backeljau, T., Vlaeminck, C., VierStraete, A., Vanfleteren, J., VincX, M. \& Moens, T. (2007). Spatiotemporal analysis of population genetic structure in Geomonhystera disjuncta (Nematoda, Monhysteridae) reveals high levels of molecular diversity. Marine Biology 151, 1799-1812.

Derycke S., Fonseca, G., Vierstraete, A., VanFleteren, J., VincX, M. \& Moens, T. (2008). Disentangling taxonomy within the Rhabditis (Pellioditis) marina (Nematoda, Rhabditidae) species complex using molecular and morphological tools. Zoological Journal of the Linnean Society $152,1-15$.

DeSalle, R., Egan, M.G. \& Siddall, M. (2005). The unholy trinity: taxonomy, species delimitation and DNA barcoding. Philosophical Transactions of the Royal Society, London B 360, 1905-1916.

DoRRIS, M., VineY, M.E. \& BlaXter, M.L. (2002). Molecular phylogenetics analysis of the genus Strongyloides and related nematodes. International Journal of Parasitology 32, 1507-1517.

EKREM, T., Willassen, E. \& STUR, E. (2007). A comprehensive DNA sequences library is essential for identification with DNA barcodes. Molecular Phylogenetics and Evolution 43, 530-542.

FÉLIX, M.A., De Ley, P., SOMMER, R.J., Frisse, L.M., NADler, S.A., Thomas, W.K., Vanfleteren, J.R. \& SternberG, P.W. (2000). Evolution of vulva development in the Cephalobina (Nematoda). Developmental Biology 221, 68-86.

Floyd, R.M., Abebe, E., Papert, A. \& Blaxter, M.L. (2002). Molecular barcodes for soil nematode identification. Molecular Ecology 11, 839-850.

FlOYd, R.M., ROgers, A.D., LAmbshead, P.J. \& SMith, C.R. (2005). Nematode-specific PCR primers for the $18 \mathrm{~S}$ small subunit rRNA. Molecular Ecology Notes 5, 611-612.

FonseCA, G., DerycKe, S. \& MoEns, T. (2008). Integrative taxonomy in two free-living nematode species complexes. Biological Journal of the Linnean Society 94, 737-753.

FonTANILLA, I.K.C. \& WADE, C.M. (2008). The small subunit (SSU) ribosomal (r) RNA gene as a genetic marker for identifying infective 3rd juvenile stage Angiostrongylus cantonensis. Acta Tropica 105, 181-186.
Foucher, A.L.J.L., Bongers, T., Noble, L.R. \& WiLSON, M.J. (2004). Assessment of nematode biodiversity using DGGE of 18S rDNA following extraction of nematodes from soil. Soil and Biochemistry 36, 2027-2032.

FRÉZAL, L. \& LEBLOIS, R. (2008). Four years of DNA barcoding: current advances and prospects. Infection, Genetics and Evolution 8, 727-736.

GASSER, R.B. \& NEWTON, S.E. (2000). Genomic and genetic research on bursate nematodes: significance, implications and prospects. International Journal for Parasitology 30, 509534.

Godfray, H.C.J. (2002). Challenges for taxonomy - the discipline will have to reinvent itself if it is to survive and flourish. Nature 417, 17-19.

Golden, T.R. \& Melov, S. (2004). Microarray analysis of gene expression with age in individual nematodes. $\underline{\text { Aging Cell }}$ 3,111-124.

HaJibabaei, M., Singer, G.A.C., Hebert, P.D.N. \& HICKEY, D.A. (2007). DNA barcoding: how it complements taxonomy, molecular phylogenetics and population genetics. Trends in Genetics 23, 167-172.

Hebert, P.D.N. \& Gregory, T.R. (2005). The promise of DNA barcoding for taxonomy. Systematic Biology 54, 852859.

Hebert, P.D.N., Cywinska, A., BALl, S.L. \& DewaARd, J.R. (2003a). Biological identifications through DNA barcodes. Proceedings of the Royal Society, London B 270, 313321.

Hebert, P.D.N., Ratnasingham, S. \& DewaARd, J.R. (2003b). Barcoding animal life: cytochrome c oxidase subunit 1 divergences among closely related species. Proceedings of the Royal Society, London B 270, 96-99.

Hebert, P.D.N., Penton, E.H., Burns, J.M., Janzen, D.H. \& HallwaChs, W. (2004). Ten species in one: DNA barcoding reveals cryptic species in the neotropical skipper butterfly Astraptes fulgerator. Proceedings of the National Academy of Sciences of the United States of America 101, 14812-14817.

HOLLINGSWORTH, B.D. (1998). The systematics of chuckwallas (Sauromalus) with a phylogenetic analysis of other iguanid lizards. Herpetology Monographs 12, 38-191.

Holterman, M., VAn Der Wurv, A., van Den Elsen, S., van Megen, H., Bongers, T., Holovachov, O., BAKKer, J. \& Helder, J. (2006). Phylum-wide analysis of SSU rDNA reveals deep phylogenetic relationships among nematodes and accelerated evolution towards crown clades. Molecular Biology and Evolution 23, 1792-1800.

Holterman, M., Rybarczyk, K., VAn DEN Elsen, S., van Megen, H., Mooyman, P., Peña Santiago, R., Bongers, T., BAKKer, J. \& HELder, J. (2008). A ribosomal DNA-based framework for the detection and quantification of stress-sensitive nematode families in terrestrial habitats. Molecular Ecology Resources 8, 23-34. 
Janzen, D.H., HaJibabaei, M., Burns, J.M., Hallwachs, W., Remigio, E. \& Hebert, P. (2005). Wedding biodiversity inventory of a large complex Lepidoptera fauna with DNA barcoding. Philosophical Transactions of the Royal Society, London B 360, 1835-1845.

KOHLER, F. (2007). From DNA taxonomy to barcoding - how a vague idea evolved into a biosystematic tool. Zoosystematics and Evolution 83, 44-51.

Kumari, S., Decraemer, W., Traversa, D. \& LišKová, M. (2009). Molecular and morphological delineation of Longidorus poessneckensis Altherr, 1974 (Nematoda: Dorylaimida). European Journal of Plant Pathology 123, 125-137.

LAmbSheaD, P.J.D. (1993). Recent developments in marine benthic biodiversity research. Oceanis 19, 5-24.

LAMBSHEAD, P.J.D. (2004). Marine nematode biodiversity. In: Chen, Z.X., Chen, S.Y. \& Dickson, D.W. (Eds). Nematology: advances and perspectives, volume 1: Nematode morphology, physiology and ecology. Wallingford, UK, CABI Publishing, pp. 436-467.

LEE, M.S.Y. (2004). The molecularisation of taxonomy. Invertebrate Systematics 18, 1-6.

LiPSCOMB, D., PlatNicK, N. \& Wheeler, Q. (2003). The intellectual content of taxonomy: a comment on DNA taxonomy. Trends in Ecology and Evolution 18, 65-68.

Litvaitis, M.K., Bates, J.W., Hope, W.D. \& MoEns, T. (2000). Inferring a classification of the Adenophorea (Nematoda) from nucleotide sequences of the D3 expansion segment (26/28S rDNA). Canadian Journal of Zoology 78, 911-922.

LORENZ, J.G., JACKSON, W.E., BECK, J.C. \& HANNER, R. (2005). The problems and promise of DNA barcodes for species diagnosis of primate biomaterials. Philosophical Transactions of the Royal Society, London B 360, 1869-1877.

LUNT, D.H. \& HYMAN, B.C. (1997). Animal mitochondrial DNA recombination. Nature 387, 247.

MALLET, J. \& WiLLmotT, K. (2003). Taxonomy: renaissance or Tower of Babel? Trends in Ecology and Evolution 18, 57 59.

MARShall, E. (2005). Taxonomy. Will DNA barcodes breathe life into classification? Science 307, 1037.

Meldal, B.H.M., Debenham, N.J., De Ley, P., De Ley, I.T., VANFleteren, J.R., Vierstraete, A.R., Bert, W., Borgonie, G., Moens, T., Tyler, P.A. ET AL. (2007). An improved molecular phylogeny of the Nematoda with special emphasis on marine taxa. Molecular Phylogenetics and Evolution 42, 622-636.

Meusnier, I., Singer, G.A.C., LAndry, J.F., Hickey, D.A., Hebert, P.D.N. \& Hajibabaei, M. (2008). A universal DNA mini-barcode for biodiversity analysis. $\mathrm{BMC} \mathrm{Ge}$ nomics $9,214$.

MEYeR, C.P. \& PaUlay, G. (2005). DNA barcoding: Error rates based on comprehensive sampling. Public Library of Science Biology 3, 2229-2238.

Moritz, C. \& CICERO, C. (2004). DNA barcoding: promise and pitfalls. Public Library of Science Biology 2, 1529-1531.
Powers, T.O., Todd, T.C., Burnell, A.M., Murray, P.C.B., Fleming, C.C., Szalanski, A.L., Adams, B.A. \& HARRIS, T.S. (1997). The rDNA internal transcribed spacer region as a taxonomic marker for nematodes. Journal of Nematology 29, 441-450.

RACH, J., DESALle, R., SARKAR, I.N., SCHIERWATER, B. \& HADRYS, H. (2008). Character-based DNA barcoding allows discrimination of genera, species and populations in Odonata. Proceedings of the Royal Society, London B 275, 237-247.

RUBINOFF, D. (2006). DNA barcoding evolves into the familiar. Conservation Biology 20, 1548-1549.

RuBinOFF, D., CAMERON, S. \& WILL, K. (2006). A genomic perspective on the shortcomings of mitochondrial DNA for "barcoding" identification. Journal of Heredity 29, 1-14.

Rusin, L.Y., Aleshin, V.V., Tchesunov, A.V. \& ATRASHKEVICH, G.I. (2003). The 18 S ribosomal RNA gene of Soboliphyme baturini Petrow, 1930 (Nematoda: Dioctophymida) and its implications for phylogenetic relationships within Dorylaimia. Nematology 5, 615-628.

SAVOlainen, V., CoWAN, R.S., VOGLER, A.P., RODERICK, G.K. \& LANE, R. (2005). Towards writing the encyclopedia of life: an introduction to DNA barcoding. Philosophical Transactions of the Royal Society, London B 360, 1805-1811.

SCHULZE, A. \& DOWNWARD, J. (2001). Navigating gene expression using microarrays - a technology review. Nature Cell Biology 3, 190-195.

Seberg, O., Humphries, C.J., Knapp, S., Stevenson, D.W., Petersen, G., ScharfF, N. \& Andersen, N.M. (2003). Shortcuts in systematics? A commentary on DNAbased taxonomy. Trends in Ecology and Evolution 18, 63-65.

Sites, J.W. \& MARShALL, J.C. (2003). Delimiting species: a renaissance issue in systematic biology. Trends in Ecology and Evolution 18, 462-470.

STOECKLE, M. (2003). Taxonomy, DNA, and the barcode of life. Bioscience 53, 796-797.

Subbotin, S.A., Sturhan, D., Vovlas, N., Castillo, P., Tambe, J.T., Moens, M. \& Baldwin, J.G. (2007). Application of the secondary structure model of rRNA for phylogeny: D2-D3 expansion segments of the LSU gene of plant-parasitic nematodes from the family Hoplolaimidae Filipjev, 1934. Molecular Phylogenetics and Evolution 43, 881-890.

SUNNUCKS, P. (2000). Efficient genetic markers for population biology. Trends in Ecology and Evolution 5, 199-203.

Tautz, D., Arctander, P., Minelli, A., Thomas, R.H. \& Vogler, A.P. (2003). A plea for DNA taxonomy. Trends in Ecology and Evolution 18, 71-74.

Tenente, G., De Ley, P., De Ley, I.T. \& Karssen, G. (2004). Sequence analysis of the D2/D3 region of the large subunit rDNA from different Meloidogyne isolates. Nematropica 34, 1-12.

Thomas, W.K., VIDA, J.T., Frisse, L.M., MUndo OCAMPO, M. \& BALDWIN J.G. (1997). DNA sequences from formalin-fixed nematodes: integrating molecular and 
morphological approaches to taxonomy. Journal of Nematology 29, 250-254.

Tringe, S.G. \& RUbin, E.M. (2005). Metagenomics: DNA sequencing of environmental samples. Nature Reviews Genetics 6, 805-814.

Valdecasas, A.G., Williams, D. \& Wheeler, Q.D. (2008). 'Integrative taxonomy' then and now: a response to Dayrat (2005). Biological Journal of the Linnean Society 93, 211-216.

VANFleteren, J.R. \& Vierstraete, A.R. (1999). Insertional RNA editing in metazoan mitochondria: the cytochrome $\mathrm{b}$ gene in the nematode Teratocephalus lirellus. RNA 5, 622-624.

Vogler, A.P. \& Monaghan, M.T. (2007). Recent advances in DNA taxonomy. Journal of Zoological Systematics and Evolutionary Research 45, 1-10.

WARD, R.D., ZEMLAK, T.S., INNES, B.H., LAST, P.R. \& HEBERT, P.D.N. (2005). DNA barcoding Australia's fish species. Philosophical Transactions of the Royal Society, London B 360, 1847-1857.

WHEELER, Q.D. (2004). Taxonomic triage and the poverty of phylogeny. Philosophical Transactions of the Royal Society, London B 359, 571-583.

WILL, K.W. \& RUBINOFF, D. (2004). Myth of the molecule: DNA barcodes for species cannot replace morphology for identification and classification. Cladistics 20, 47-55.

Will, K.W., Mishler, B.D. \& WheEleR, Q.D. (2005). The perils of DNA barcoding and the need for integrative taxonomy. Systematic Biology 54, 844-851.

WILSON, E.O. (2004). Taxonomy as a fundamental discipline. Philosophical Transactions of the Royal Society, London B 359, 739 .

Zheng, J., Subbotin, S.A., He, S., Gu, J. \& Moens, M. (2003). Molecular characterisation of some Asian isolates of Bursaphelenchus xylophilus and B. mucronatus using PCRRFLPs and sequences of ribosomal DNA. Russian Journal of Nematology 11, 17-22.

\section{Appendix A}

Table A1. Molecular markers used in studies with marine nematodes.

\begin{tabular}{|c|c|c|c|}
\hline Primer & $\begin{array}{l}\text { Position of } \\
\text { amplicons* }\end{array}$ & Sequence $\left(5^{\prime} \rightarrow 3^{\prime}\right)$ & Source \\
\hline \multicolumn{4}{|l|}{ Nuclear genes } \\
\hline \multicolumn{4}{|l|}{$18 \mathrm{~S}-\mathrm{SSU}$} \\
\hline \multirow[t]{4}{*}{ SSUG18S } & $30-49$ & GCT TGT CTC AAA GAT TAA GCC & Blaxter et al. (1998) \\
\hline & & & Meldal et al. (2007) \\
\hline & & & Bhadury et al. (2005) \\
\hline & & & Bert et al. (2008) \\
\hline SSUA & $39-57$ & AAAGATTAAGCCATGCATG & Dorris et al. (2002) \\
\hline \multirow[t]{4}{*}{ SSU22R } & $429-411$ & GCC TGC TGC CTT CCT TGG A & Blaxter et al. (1998) \\
\hline & & & Meldal et al. (2007) \\
\hline & & & Bhadury et al. (2007) \\
\hline & & & Bert et al. (2008) \\
\hline SSU22F & $411-428$ & TCC AAG GAA GGC AGC AGG C & Blaxter et al. (1998) \\
\hline \multirow[t]{2}{*}{ SSU9FX } & $530-550$ & AAG TCT GGT GCC AGC AGC CGC & Meldal et al. (2007) \\
\hline & & & Bert el al (2008) \\
\hline SSU9F & $573-591$ & CGCGGTAATTCCAGCTCCA & Blaxter et al. (1998) \\
\hline \multirow[t]{2}{*}{ SSU9R } & $584-565$ & AGC TGG AAT TAC CGC GGC TG & Blaxter et al. (1998) \\
\hline & & & Bert et al. (2008) \\
\hline \multirow[t]{2}{*}{ SSU24F } & $868-887$ & AGR GGT GAA ATY CGT GGA CC & Blaxter et al. (1998) \\
\hline & & & Meldal et al. (2007) \\
\hline SSU 24R & $885-868$ & CCCCRRTCCAAGAATTTCACCTC & Meldal et al. (2007) \\
\hline SSU26R & $927-907$ & CATTCTTGGCAAATGCTTTGC & Blaxter et al. (1998) \\
\hline \multirow[t]{2}{*}{ SSU23F } & $1280-1298$ & ATT CCG ATA ACG AGC GAG A & Blaxter et al. (1998) \\
\hline & & & Bert el al. (2008) \\
\hline
\end{tabular}


N.R. Rodrigues da Silva et al.

Table A1. (Continued).

\begin{tabular}{|c|c|c|c|}
\hline Primer & $\begin{array}{l}\text { Position of } \\
\text { amplicons* }\end{array}$ & Sequence $\left(5^{\prime} \rightarrow 3^{\prime}\right)$ & Source \\
\hline SSU23R & $1298-1280$ & TCT CGC TCG TTA TCG GAA T & $\begin{array}{l}\text { Blaxter et al. (1998) } \\
\text { Bert et al. (2008) }\end{array}$ \\
\hline SSU13R & $1438-1419$ & GGG CAT CAC AGA CCT GTT A & Blaxter et al. (1998) \\
\hline SSU18P & $3^{\prime}$ end & TGA TCC WMC RGC AGG TTC AC & $\begin{array}{l}\text { Blaxter } \text { et al. }(1998) \\
\text { Bert } \text { et al. }(2008)\end{array}$ \\
\hline SSU2FX & $1108-1129$ & GGA AGG GCA CCA CCA GGA GTG G & Meldal et al. (2007) \\
\hline SSUDR & $1213-1194$ & CATAAAAGTCTCGCTCGTTA & Dorris et al. (2002) \\
\hline NM18F & $345-925$ & CGCGAATRGCTCATTACAACAGC & $\begin{array}{l}\text { Bhadury et al. (2008) } \\
\text { Bhadury et al. (2006) } \\
\text { Bhadury et al. (2007) }\end{array}$ \\
\hline Nem 18SF & & CGCGAATRGCTCATTACAACAGC & Floyd et al. (2005) \\
\hline Nem 18SR & $998-1015$ & GGGCGGTATCTGATCGCC & $\begin{array}{l}\text { Bhadury et al. }(2008) \\
\text { Bhadury et al. }(2006 \mathrm{a}, \mathrm{b}) \\
\text { Floyd et al. }(2005)\end{array}$ \\
\hline
\end{tabular}

$\begin{array}{lcl}\text { ITS } & & \\ \text { RDNA2 } & 2523-2503 & \text { TTG ATT ACG TCC CTG CCC TTT } \\ \text { rDNA1.58S } & - & \text { ACG AGC CGA GTG ATC CAC CG } \\ \text { rDNA 2.144 } & - & \text { GTA GGT GAA CCT GCA GAT GGA T } \\ \text { VRAIN 2F } & 900 & \text { CTTTGTACACACCGCCCGTCGCT } \\ \text { VRAIN 2R } & 900 & \text { TTTCACTCGCCGTTACTAAGGGAATC }\end{array}$

28S - LSU

LSU rDNA-D2A

LSU rDNA-D3B

397

397

TTCGACCCGTCTTGAAACACG

TCGGAAGGAACCAGCTACTA

ATGTTTTGATTTTACCWGCWTTYGGTGT

TTTTTTGGGCATCCTGAGGTTTAT

TAAAGAAGAACATAATGAAAATG AGCACCTAAACTTAAAACATARTGRAARTG CCCCTCTAGTCTWCTATTTCTTAATAC
Powers et al. (1997)

Powers et al. (1997)

Powers et al. (1997)

Derycke et al. (2005)

Derycke et al. (2008)

Derycke et al. (2005)

Derycke et al. (2008)

Fonseca et al. (2008)

De Ley et al. (2005)

Derycke et al. (2008)

Fonseca et al. 2008

De Ley et al. (2005)

Derycke et al. (2008)

Derycke et al. (2005)

Derycke et al. (2006)

Derycke et al. (2007)

Derycke et al. (2005)

Derycke et al. (2006)

Derycke et al. (2007)

Derycke et al. (2007)

Derycke et al. (2007)

Derycke et al. (2007)

Uncoming genes

Minibarcode-COI

Minibar-R1 _ $\quad$ GAAAATCATAATGAAGGCATGAGC

Minibar-F1

- $\quad$ TCCACTAATCACAARGATATTGGTAC

Meusnier et al. (2008)

Meusnier et al. (2008)

\footnotetext{
* Position of amplicon in relation to Caenorhabditis elegans.
} 